\title{
Monitoring Impacts of Human Activities on Bouskoura Stream (Periurban of Casablanca, Morocco): 3. Bio-Ecology of Epilithic Diatoms (First Results)
}

\author{
Lhoucine Benhassane*†, Said Oubraim**, Jihad Mounjid**, Souad Fadlaoui** and Mohammed Loudiki*** \\ * Laboratory of Ecology and Environment, Department of Biology, Faculty of Sciences Ben M'Sik, Hassan II University \\ of Casablanca, Morocco or Public Laboratory for Tests and Studies, Center for Studies and Research on the Environment \\ and Pollution, Casablanca, Morocco \\ **Laboratory of Ecology and Environment, Department of Biology, Faculty of Sciences Ben M'Sik, Hassan II Universi- \\ ty of Casablanca, Morocco \\ ***Laboratory of Algology, Semlalia Faculty of Sciences in Marrakech, Morocco \\ $\dagger$ Corresponding author: Lhoucine Benhassane; h.benhassane@gmail.com
}

Nat. Env. \& Poll. Tech. Website: www.neptjournal.com

Received: 31-01-2020

Revised: 11-02-2020

Accepted: 02-05-2020

Key Words:

Water quality

Pollution

Epilithic diatoms

Bio-ecology

\begin{abstract}
The epilithic diatoms of a periurban watercourse of Casablanca city (Bouskoura stream) were studied from samples taken in 8 stations (distributed in the upstream-downstream direction) for two years (August 2015-July 2017). The recorded diatomic flora consists of 54 species corresponding to 27 genera and belonging to 5 main families: Monoraphids, Naviculaceae, Nitzschiaceae, Araphids and Surirellaceae. This flora is predominantly alkaliphile and characterizes $\beta$-mesosaprobe to polysaprobes and eutrophic to hypereutrophic media. Responses assemblage to natural and anthropogenic disturbances were analyzed. Diatom assemblages structure analysis shows that downstream of this watercourse, where pollution is intense, the abundances of pollosensitive taxa such as Achnanthes minutissima, Cymbella affinis are low or even nulls and we are witnessing the appearance of polysaprobe forms such as Nitzschia palea, Nitzschia capitellata and Nitzschia frustulum that tolerate rich environments in organic matter or highly polluted. Spatial variation in species diversity could not highlight changes in water quality at the prospected sites; on the other hand, the change in the percentage of pollutant-tolerant taxa (PTV) revealed the full extent of the alteration due to gradual nutrient and organic matter inputs into the Bouskoura watercourse. In addition, the correlation obtained between this index and the organic pollution index (IPO) is highly significant. Principal component analysis (PCA) highlighted taxonomic differences between stations. The results obtained in this work have emphasized the importance of diatoms as a bioindicator of the health status of this periurban watercourse.
\end{abstract}

\section{INTRODUCTION}

The problem of the deterioration of aquatic ecosystems and the water quality of watercourses in particular, is an increasingly important issue in the world and more particularly in countries with an arid and semi-arid climate such as than Morocco. These concerns are intimately related to the uses that man makes of them.

Different tools can be used to evaluate the lotic environments quality and the disturbances they undergo. The majority of the work on monitoring the quality of these environments in Morocco relies on physicochemical and microbiological methods of water samples taken occasionally in different sampling stations as well as on the use of macroinvertebrates as bioindicators of health of these hydrosystems. The first studies on diatoms in Morocco targeted the flora of stagnant waters (Hariot 1909, Gauthier 1930, Gattefosse 1935, Gayral 1954 etc). Subsequently, there has been little work on diatoms as a biological tool for assessing the quality of Moroccan lotic media (Werner 1949, Maiffi-Rassat 1988 and Cazaubon \& Badri 1994 on the Tensift River, Fekhaoui et al. 1988 and Jaghror et al. 2017 on the Sebou River in addition to the work of Fawzi et al. 2001 and Fawzi et al. 2002 on Hassar stream).

This study is part of a research program aimed at characterizing the aquatic environment and water quality in the Moroccan Chaouia coastal watershed. It consists of evaluating the ecological status of the Bouskoura stream (suburban of Casablanca) by using diatom communities as bioindicators, and this, in relation to the physicochemical quality of the water. To date, studies on this hydrosystem have focused on macroinvertebrate, physicochemical and bacteriological components (Tazi et al. 2001, Mounjid et al. 2014, Benhassane et al. 2019) or the modelling of this watercourse (Stoffnerr 2013, Goury \& Chelhaoui 2013, Boudaoud \& Hadine 2013). The evaluation of its biological quality using diatoms has been omitted. 
The choice of benthic diatoms in this study is justified by the fact that the quality of running waters is reflected in the composition of their assemblages (Round 1991). In fact, the different diatom species have a high sensitivity to the conditions of their aquatic environment (Fièvet et al. 2003, Stenger-Kovácsa et al. 2013, Kollár et al. 2015). These aquatic organisms are in constant physical, chemical and biological interaction with their ecosystem. They are thus able to integrate environmental evolutions in the short term as well as in the long term, but also the antagonistic or synergistic effects of the different types of contaminants, impossible to demonstrate by physicochemical measurements (Whitton 1991). In order to have a better appreciation of the real biological quality in a river, Torrisi et al. (2006) recommended that epilithic rather than epiphytic diatoms be preferentially sampled for the following reasons:

- Epilithic communities are more representative and more diverse than strictly epiphytic communities.

- In addition, stones are a frequent, inert, stable and homogeneous natural substrate in streams.

Finally, this work will also test the importance of using diatoms as a practical tool for estimating the overall quality of Bouskoura stream.

\section{MATERIALS AND METHODS}

\section{Study Area and Sampling Stations}

Bouskoura stream, a $20 \mathrm{~km}$ long and $10 \mathrm{~L} / \mathrm{s}$ average flow, is located $10 \mathrm{~km}$ south of Casablanca city. This watercourse, fed by five main sources which drain the waters of the coastal Chaouia groundwater (Fig. 1). After $11 \mathrm{~km}$, this stream receives the waters of its left tributary (Ain Joumaa). Bouskoura stream flows from south to north of the Casablanca city while irrigating 20 ha of the area of its catchment area estimated at $255 \mathrm{~km}^{2}$ (Stoffnerr 2013).

This hydrosystem crosses the central zone of Casablanca where its natural bed is completely urbanized and the watercourse becomes channelled.

From the upstream to downstream, 8 sampling stations (including 2 stations belonging to the control network of the Bouregreg-Chaouia ABHBC Hydraulic Basin Agency) were positioned on the main course of Bouskoura and its tributary (Ain Joumaa) to target the sections of this hydrosystem that are the most degraded in terms of ecological integrity (Fig. 1). The Lambert coordinates for these stations are shown in Table 1.

The choice of these stations is based on the nature of the water (wastewater, natural waters), the morphological
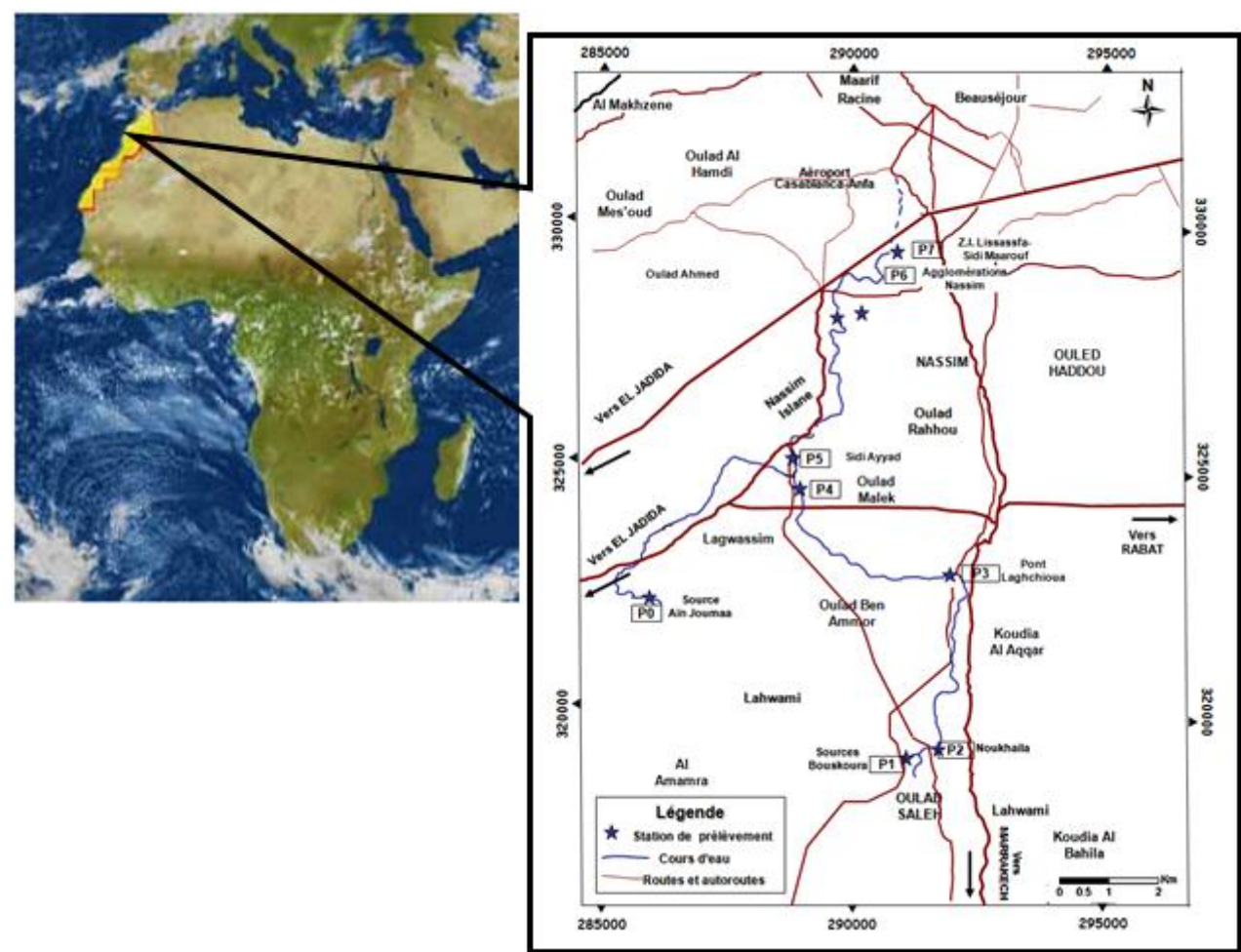

Fig. 1: Study area and sampling stations in the Bouskoura stream. 
Table 1: Coordinates, characteristics and type of activities in monitoring stations in Bouskoura stream.

\begin{tabular}{|llllll|}
\hline Stations & \multicolumn{2}{c}{ Lambert Coodinates } & $\begin{array}{l}\text { Distance between } \\
\text { station }(\mathrm{km})\end{array}$ & $\begin{array}{l}\text { Total distance } \\
(\mathrm{km})\end{array}$ & Type of pollution \\
\cline { 2 - 5 } & $\mathrm{X}$ & $\mathrm{Y}$ & & - & Bathing activity \\
\hline P0 (Aïn Joumaa Source) & 286190 & 322244 & - & 0 & Reference station \\
P 1 (Bouskoura Source) & 291150 & 318980 & - & 0.353 & Domestic and industrial pollution \\
P 2 (Noukhayla) & 291364 & 319230 & 0.353 & 5.079 & Agricultural pollution \\
P 3 (Laghchiwa Bridge) & 291933 & 322716 & 4.726 & 8.989 & Agricultural pollution domestic pollution \\
P 4 (Oulad malek) & 288948 & 323808 & 3.91 & 11.429 & Agricultural pollution \\
P 5 (Sidi Ayyad) & 288830 & 325255 & 2.44 & 14.435 & Domestic pollution \\
P 6 (Nassim Agglomerations) & 289582 & 327110 & 3.006 & 15.547 & Industrial pollution \\
P 7 (Lissasfa-Sidi Maârouf Industrial Zone) & 289733 & 328117 & 1.112 & & \\
\hline
\end{tabular}

structure of the Bouskoura watercourse, the nature of the bed and substrate, the proximity of urban and rural population centres and the possibilities of access and sampling offered.

\section{Physico-Chemical Analyses}

Between August 2015 and July 2017, 11 to 12 water samples have been carried out at the above-mentioned stations. The water samples taken were subjected to physico-chemical analyses to measure $\mathrm{pH}$, temperature, dissolved oxygen $\left(\mathrm{O}_{2}\right)$, electrical conductivity, suspended matter (SM), ammonium ions $\left(\mathrm{NH}_{4}^{+}\right)$, nitrites $\left(\mathrm{NO}_{2}^{-}\right)$, nitrates $\left(\mathrm{NO}_{3}^{-}\right)$, orthophosphates $\left(\mathrm{PO}_{4}{ }^{3-}\right)$, total phosphorus (TP), total Kjeldahl nitrogen (TKN), chemical oxygen demand (COD), biochemical oxygen demand for five days $\left(\mathrm{BOD}_{5}\right)$ and chlorophyll a (Chl a).

The samples of water to be analyzed were directly carried out in polyethene bottles of $500 \mathrm{~mL}$, stored in a cooler at $4^{\circ} \mathrm{C}$ and then transported to the laboratory for analysis. Analyses of different chemical parameters were carried out, in accordance with French standard (NF T 90-354, 2000), at the Laboratory of Ecology and Environment of the Faculty of Sciences Ben M'Sik -Casablanca (Morocco).

All equipment was calibrated and verified with certified standards to ensure reliable results.

\section{Sampling, Treatment and Determination of Diatoms}

Samples of epilithic diatoms were made on a mineral substrate according to the French standard (NF EN 13946, 2003). After cleaning with concentrated hydrogen peroxide, the diatoms are mounted in the naphtha resin $(I R=1.74)$ for observation under a microscope according to the procedure described by the French standard (NF T90 354, 2003). According to this standard, each microscopic preparation has been counted to a minimum of 400 valves.

The determinations were made at the specific or even infra-specific level according to Krammer \& Lange-Bertalot (1986, 1988, 1991a and 1991b), Round et al. (1990) and Bey et al. (2013).

\section{Structural Indices of Diatomic Communities}

Specific diversity (H') of Shannon and Weaver (1963): The diatom specific diversity was determined at the different Bouskoura stream sites by the Shannon and Weaver index (1963). This index makes it possible to measure the heterogeneity of the biodiversity of an environment; it was calculated using the following formula:

$$
\mathbf{H}^{\prime}=-\sum_{i=1}^{\mathrm{s}} \frac{n_{i}}{\mathrm{~N}} \log _{2}\left(\frac{n_{i}}{\mathrm{~N}}\right)
$$

Where,

ni: Number of individuals of the species $i$

$\mathrm{n}$ : Total number of individuals in the sample

$\mathrm{H}^{\prime}$ : Expressed in bits (information unit)

S: Total number of species

Wilhm (1975) gave a water quality classification based on the values of the Shannon-Weaver Diversity Index (1963) as shown in Table 2:

Pielou evenness (1975): The Pielou index (1975) is the ratio of the calculated diversity to an optimal theoretical diversity, $\mathrm{H}_{\max }$, obtained by considering that each of the $\mathrm{S}$ species in the sample is represented by a single individual.

$$
\begin{gathered}
\mathrm{H}_{\max }=\log _{2} \mathrm{~S} \\
\text { Evenness } \mathrm{E}=\left(\mathrm{H}^{\prime} / \log _{2} \mathrm{~S}\right)
\end{gathered}
$$

Jaccard similarity coefficient (1901): The similarity coefficient of Jaccard (1901) allows a comparison between two sites, by evaluating the similarity between two records and by comparing the species common to both records and those

Table 2: Interpretation of the Shannon-Weaver Diversity Index H' (after Wilhm 1975).

\begin{tabular}{|ll|}
\hline$H^{\prime}$ & water quality \\
\hline$<3$ & Little or no polluted \\
$1<H^{\prime}<3$ & Moderately polluted \\
$H^{\prime}<1$ & Very polluted \\
\hline
\end{tabular}


specific to each survey.

From the presence-absence matrix, the Jaccard similarity index can be calculated easily according to the following formula:

Jaccard similarity coefficient $\mathrm{I}_{\mathrm{J}}=\mathrm{N}_{\mathrm{c}} /\left(\mathrm{N}_{\mathrm{a}}+\mathrm{N}_{\mathrm{b}}-\mathrm{N}_{\mathrm{c}}\right) \ldots(4)$

Where,

$\mathbf{N}_{\mathbf{c}}$ : Number of taxa common to stations $\mathrm{a}$ and $\mathrm{b}$

$\mathbf{N}_{a}$ et $\mathbf{N}_{\mathbf{b}}$ : Number of taxa present in stations a and $b$, respectively

Organic pollution index (OPI): This index is calculated by integrating the concentrations of 4 chemical parameters related to organic pollution: Biological Oxygen Demand $\left(\mathrm{BOD}_{5}\right)$, ammonium ions $\left(\mathrm{NH}_{4}^{+}\right)$, nitrites $\left(\mathrm{NO}_{2}^{-}\right)$and phosphates $\left(\mathrm{PO}_{4}{ }^{3-}\right)$. Each of them is distributed in 5 classes (Table 3) which have a biological significance corresponding to typical diatom changes (Leclercq \& Vandevenne 1987). After Leclercq \& Maquet (1987), OPI is the mean value of the classes found for each parameter and gives a five-level pollution index (Table 4).

The percentage of pollution tolerant valves (\% PTV): The impact of anthropogenic activities on the structure of the diatomic community has been estimated from the percentage of tolerant species to organic pollution (\%PTV). The selection of these species was made according to Van Dam et al. (1994) who took into consideration in his work the preferences of 948 species of freshwater and brackish diatoms in terms of $\mathrm{pH}$, nitrogen, oxygen, salinity, humidity, saprobity and trophic status.

\% PTV was developed by Kelly (1998) and Kelly \& Whitton (1995) to monitor sewage effluent (orthophosphate-phosphorus concentrations) and not the overall quality of watercourses. The presence of more than $20 \%$ of PTV shows significant organic impact (Table 5). This index has

Table 3: Classes of the parameters for calculating the Organique Pollution Index (OPI).

\begin{tabular}{|lllll|}
\hline $\begin{array}{l}\text { Paramètres } \\
\text { Classes }\end{array}$ & $\begin{array}{l}\mathrm{BOD}_{5} \\
\left(\mathrm{mg} \mathrm{O}_{2} / \mathrm{L}\right)\end{array}$ & $\begin{array}{l}\text { ammonia } \\
(\mathrm{mg} \mathrm{N} / \mathrm{L})\end{array}$ & $\begin{array}{l}\text { nitrite } \\
(\mu \mathrm{g}-\mathrm{N} / \mathrm{L})\end{array}$ & $\begin{array}{l}\text { phosphates } \\
(\mu \mathrm{g}-\mathrm{P} / \mathrm{L})\end{array}$ \\
\hline 5 & $<2$ & $<0.1$ & 5 & 15 \\
4 & $2-5$ & $0.1-0.9$ & $6-10$ & $16-75$ \\
3 & $5.1-10$ & 2.4 & $11-50$ & $76-250$ \\
2 & $10.1-15$ & $2.5-6.0$ & $51-150$ & $251-900$ \\
1 & $>15$ & $>6$ & $>150$ & $>900$ \\
\hline
\end{tabular}

Table 4: OPI classes and corresponding pollution levels.

\begin{tabular}{|ll|}
\hline Average class number of parameters & Level of organic pollution \\
\hline $5.0-4.6$ & No pollution \\
$4.5-4.0$ & Low \\
$3.9-3.0$ & Moderate \\
$2.9-2.0$ & Strong \\
$1.9-1.0$ & Very strong \\
\hline
\end{tabular}

Table 5: Interpretation of \% PTV scores (after Kelly 1998).

\begin{tabular}{|ll|}
\hline$\%$ PTV & Interpretation \\
\hline$<20 \%$ & Free from significant organic pollution \\
$21 \%-40 \%$ & Some evidence of organic pollution \\
$41 \%-60 \%$ & $\begin{array}{l}\text { organic pollution to contribute significantly to } \\
\text { eutrophication at site }\end{array}$ \\
$>61 \%$ & Site heavily contaminated with organic pollution \\
\hline
\end{tabular}

been used by many authors around the world (Bellinger et al. 2006, Walsh \& Wepener 2009, Menye et al. 2012).

Statistical treatment: Results data were analyzed and statistically processed using Principal Component Analysis (PCA) to characterize the Diatom assemblages structure of Bouskoura stream. The PCA was performed using the STATISTICA software (v. 6.0).

For diatoms, the database used for the diatomic community typology of this hydrosystem is the average relative abundance of taxa (with a cumulative relative abundance greater than or equal to 5\%) and 8 stations.

The degree of binding between physicochemical and biological variables was assessed using the Spearman rank correlation test using the same STATISTICA software.

\section{RESULTS AND DISCUSSION}

\section{Physicochemical Quality of Water}

Spatial evolution of physicochemical parameters in Bouskoura stream: The results of physicochemical analyses of Bouskoura stream water are given in Table 6. Water temperature varies according to the sites and sampling periods. Average water temperature for the stream would be of the order of $20.88^{\circ} \mathrm{C}$. These data indicate that the temperature of the study area is favourable to aquatic life (Rodier 2009). The $\mathrm{pH}$ is around an average of about 7.69. In general, the waters of the studied hydrosystem will be slightly basic. The constancy of the $\mathrm{pH}$ can therefore be attributed, in the sense of Golterman (1971), to the buffering phenomenon of the carbonate-bicarbonate complex.

Electrical conductivity shows an upward trend along an upstream-downstream gradient. The average for all stations in the watercourse would be $3964.68 \mu \mathrm{S} / \mathrm{cm}$. These results are comparable to those reported by several authors in most Mediterranean watercourses (Oubraim 2002, Morin 2006, Mouni et al. 2009, Mounjid et al. 2014, Nehar et al. 2015, Quevedo et al. 2018 etc.).

Dissolved oxygen shows decay from upstream to downstream. The most notable falls are those recorded in P2, P6 and $\mathrm{P} 7$ where there is a deficit in oxygen (respectively 1.73; 1.29 and $0.64 \mathrm{mg} \mathrm{O}_{2} / \mathrm{L}$ ). Indeed, these stations permanently 
receive the wastewater from the Lissassfa-Sidi Maarouf industrial zone and the Nassim agglomerations and they are therefore loaded with organic matter whose degradation by the microorganisms consumes oxygen.

The nitrite averages evolution in the different stations of the Bouskoura lotic medium shows no particular tendency. The spatial variation of this parameter clearly shows significant differences between the stations testifying to the variability of the sources of pollution along this lotic ecosystem.

The analysis of the ammonium, phosphorus compounds, $\mathrm{BOD}_{5}, \mathrm{COD}$ and suspended solids profiles shows an upward trend.

The increase in phosphorus compounds may be of domestic and industrial origin but also of agricultural origin, especially since the highest values are recorded during the rainy season when leaching of phosphorus elements is important.

The average $\mathrm{BOD}_{5}$ and $\mathrm{COD}$ contents depend on the typology discharges in the different stations of Bouskoura stream. However, it is important to note that in the P2 station heavily impacted by wastewater from the Oulad Saleh industrial zone, the average value of $\mathrm{BOD}_{5}$ remains low. In fact, in the field, we notice that the wastewater of this station contains fats, oils, detergents and probably heavy metals. These pollutants are capable of inhibiting the self-purifying power of aerobic bacteria present in the water.

The average levels of chlorophyll a are low P0 station (i.e. $0.37 \mu \mathrm{g} / \mathrm{L}$ ) and then increase until reaching the value of $36.94 \mu \mathrm{g} / \mathrm{L}$ in the P3 station. This increase is followed by a gradual decrease towards downstream stations; the low concentration (i.e. $6.94 \mu \mathrm{g} / \mathrm{L}$ ) is observed at the Sidi Maars ouf-Lissassfa industrial zone (P7 station).

The ANOVA statistical test followed by the Tukey HSD posterior test applied to the means of the physicochemical parameters, shows that the differences observed between the upstream and the downstream stations are significant $(\mathrm{P}<0.05)$ for all the physicochemical parameters (at the exception of the temperature). Indeed, the evolution of these parameters illustrates a gradient of mineralization and organic pollution increasing from upstream to downstream of Bouskoura stream where the effect of human activities is significant. The strong standard deviations observed show significant intra-site variations.

\section{Epilithic Diatoms of Bouskoura stream.}

Global analysis of the diatom assemblage inventory: A total of 54 species and varieties of diatoms corresponding to
27 genera and belonging to 5 main families have been identified in the 8 stations of this hydrosystem (Table 7). Many of these taxa and varieties are cosmopolitan. Overall, this diatomic assemblage consists of species adapted, for some of them, to a high mineralization, and for others, significant eutrophication of the waters.

The taxonomic richness of diatomic assemblage in the Bouskoura watercourse is quite similar to that of several Moroccan and Mediterranean periurban rivers and streams (Table 8). Nevertheless, diatomic floral inventory of Hassar, Ul (Portugal) and Felent (Turkey) watercourses seems to be superior than in Bouskoura stream.

- The composition of diatom communities varies from upstream to downstream of Bouskoura stream. We go from assemblage characterized by species sensitive to alterations of the environment (monoraphidae, araphid and naviculaceous) to others that are composed of pollution-resistant species (polysaprobes) characterizing the disturbed environments (the Nitzschiaceae in particular).

- The main families represented are:

- Monoraphids are represented by 4 genera and 4 species (i.e. $7.4 \%$ of total species richness). This family is composed mainly of pioneer and colonizing species that are generally sensitive to environmental alterations and characterize undisturbed rivers (Prygiel \& Coste 2000).

- Naviculaceae are represented by 14 genera and 33 species (i.e. $61 \%$ of total species richness). Naviculaceae contains the largest number of very different types of ecology.

- Nitzschiaceae is composed of 4 genera that group together 11 species (i.e. $20 \%$ of the total species richness). Nitzschiaceae contains a large number of usually saprophilous or N-heterotrophic species. However, there are some sensitive and alkaliphilic forms.

- Araphideae is composed of 3 genera corresponding to 4 species representing $7.4 \%$ of total species richness.

- Surirellaceae is composed of 2 genera corresponding to 2 species representing $3.7 \%$ of the total species richness. It is very little represented in the inventories of the study stations.

- Other Brachyraphideae, Centrophycideae and Epithemia families are absent in the diatomic communities of Bouskoura. 


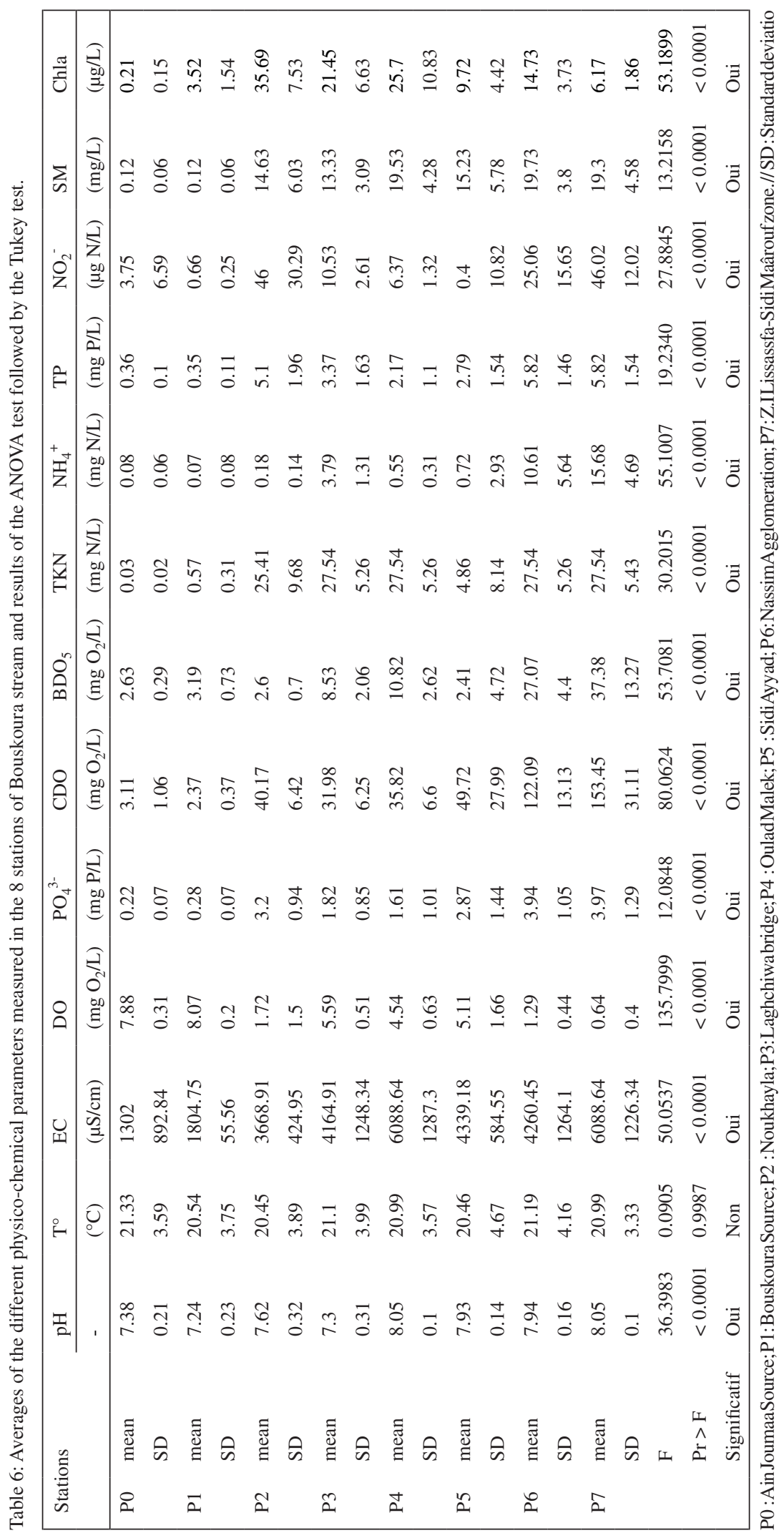




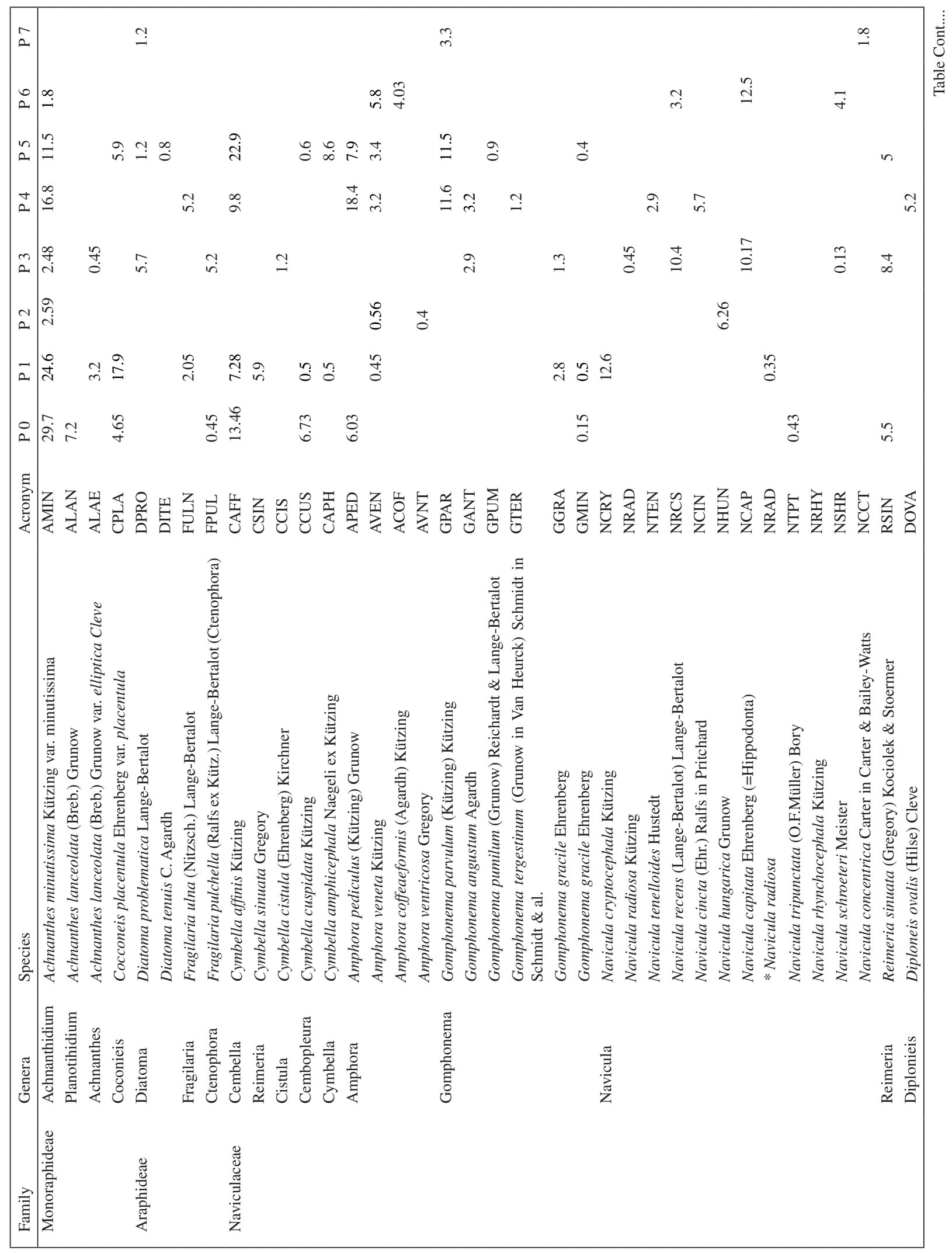




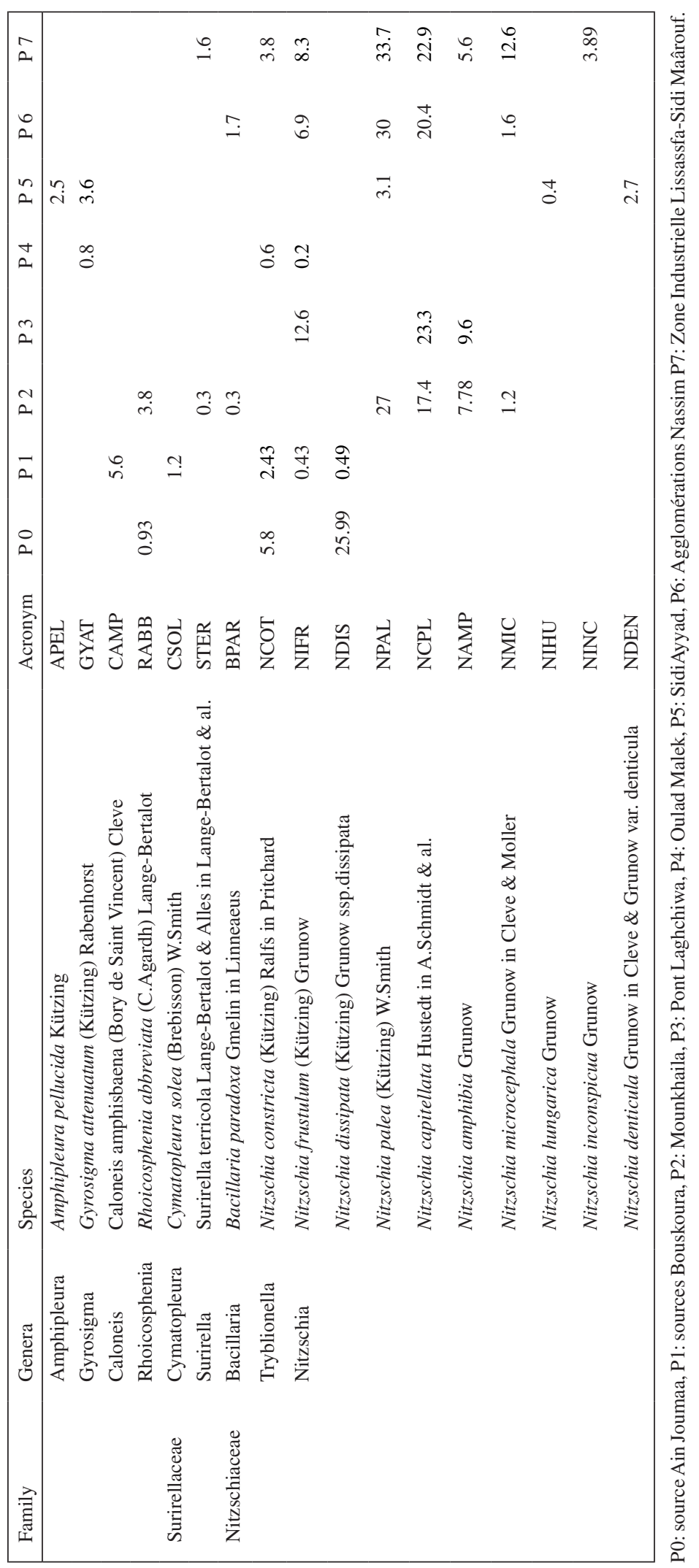


- The specific composition varies from one station to another and also within each family of diatomic flora. Nevertheless one can note a clear dominance of the species belonging to the Naviculaceae in the majority of the stations of the Bouskoura stream.

Diversity, structure and ecology of the diatom assemblage: The values of the average species richness $\mathrm{S}$ (Table 9) show an uptrend from sources P0 and P1 up to P5 (Sidi Ayyad). Beyond this, one notes a fall of this index. The average species richness $\mathrm{S}$ varies from 10 to 18 species. The highest value is noted at the P1 station (Bouskoura source) and the lowest at the P2 and P6 stations which are characterized by an untreated domestic pollutant load. It is also in these two stations that we noted the total absence of Araphidae. Similar results have been reported in the work of Slim et al. (2013) on the Hasbani watercourse (South Lebanon).

The mean values of the Shannon-Weaver H' diversity index range from 2.63 at the P6 station to 3.49 at the P5 station.

With the exception of the two stations P6 and P7, where the averages H' are the lowest (respectively 2.63 bits and 2.76 bits), this index is greater than 2.9 bits for most of the study stations, thus reflecting a homogeneous distribution of individuals within the species that make up the diatomic flora of Bouskoura stream. The values of the Shannon-Weaver diversity index $\mathrm{H}^{\prime}$ in the Bouskoura stream are similar to those obtained by Letàkova et al. (2018) in 13 watercourses of the Morava basin (Czech Republic), by Gomà et al. (2005) in the upper Segre basin (Spain) but remain higher than those obtained by Nehar et al. (2015) at El-Hammam stream (Algeria) where H' does not exceed 2.5 bits and to those obtained by Timizel et al. (2017) in Pazarsuyu stream (Turkey) where H' varied from 0.81 to 0.85 bits.

Referring to Wilhm's classification (1975), given in Table 2, stations P2, P6 and P7 would be moderately polluted while P0, P1, P3, P4 and P5 would be little or even unpolluted.

In Chícamo Stream (S-E Spain), peak diversity and species richness of the diatom communities were linked to discharge, depth, dissolved oxygen and sulfate concentrations (Ros et al. 2009). According to Patrick (1971), algal species richness and diversity increase, in general, with temperature, although this is modulated by the climatic characteristics of the basins.

In general in Bouskoura stream, it can be noted that the spatial variation of the specific diversity H' did not underline the full extent of the deterioration of the water quality, because it is noted that despite a significant inflow of raw wastewater into the P3 station (Oulad Ben Ammor) the diversity index H' showed a marked increase.

As for the diversity index, evenness (E) shows an increasing evolution from upstream (stations P0 and P1) until to station P5 (where it reaches 0.92) and then decreases downstream of this station to reach the value of 0.79 in P6 and P7. It is often accepted that evenness values equal or greater than 0.8 are synonymous with a structured and balanced population (Daget 1976). From the results of the present study, it can thus be said that globally the diatomic

Table 8: Taxonomic richness of diatomic assemblage in some Mediterranean rivers and streams.

\begin{tabular}{|c|c|c|c|}
\hline Watercourse & Country & Taxonomic richness & Reference \\
\hline Verdon river & France & 38 taxa & Millerioux et al. (1981) in Cazauban \& Badri (1991) \\
\hline Upstream of Sebou river & Morocco & 47 species & Fekhaoui et al. (1988) \\
\hline Boufekrane stream & Morocco & 5 orders, 8 families et 53 species & Hammada et al. (1996) \\
\hline Tensift river & Morocco & 73 taxa & Cazauban \& Badri (1991) \\
\hline Hassar stream & Morocco & 130 taxa & Fawzi et al. (2002) \\
\hline Akçay stream & Turkey & 78 taxa & Solak (2007) \\
\hline Ul river & Potugal & 94 taxa ( 27 genera) & Resende et al. (2010) \\
\hline Upper Porsuk Creek & Turkey & 57 taxa & Solak (2011) \\
\hline Felent creek & Turkey & 117 taxa & Solak et al. (2012) \\
\hline Murat stream & Turkey & 75 taxa & Tokatlı \& Dayı lu (2014) \\
\hline El-Hammam stream at Mascara & Algeria & 44 taxa & Nehar et al. (2015) \\
\hline Clarà stream & Spain & 59 to 74 species & Burfeid Castellanos (2018) \\
\hline Salada stream & Spain & 15 to 58 species & \\
\hline Araban-Yavuzeli catchment & Turkey & 75 taxa & Çelekli \& Bilgi (2019) \\
\hline Tohma stream & Turkey & 70 taxa & Yildirim \& Baran (2019) \\
\hline Bouskoura stream & Morocco & 5 Orders, 5 Families and 57 Species & Present study \\
\hline
\end{tabular}




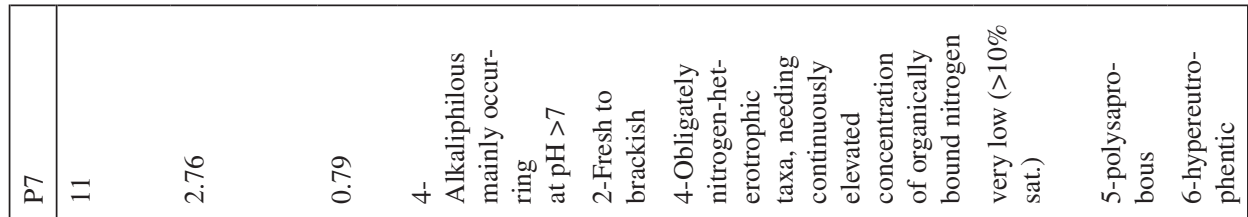

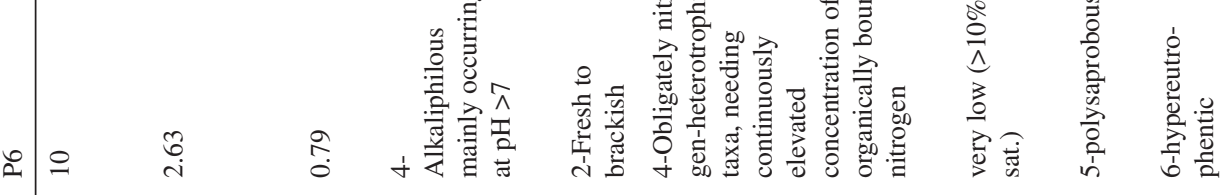

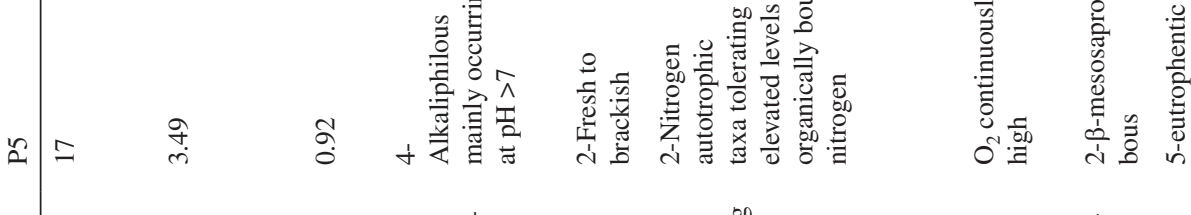

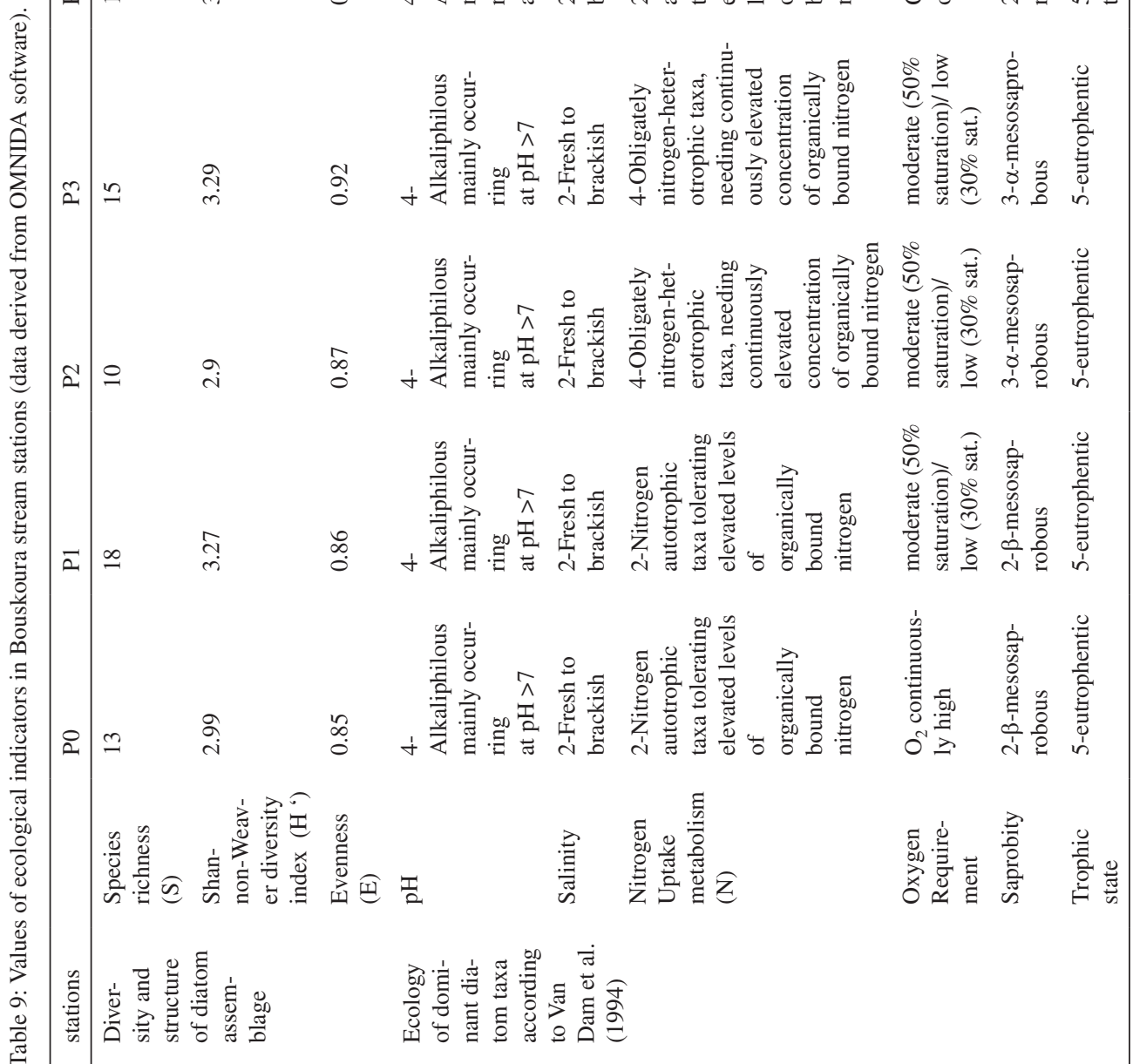


flora of the Bouskoura hydrosystem is poorly structured to well structured and balanced.

According to Van Dam (1994), the diatom communities of the Bouskoura stream indicate mainly alkaliphilic, fresh to brackish conditions. The trophic state is eutrophic (in $\mathrm{P}$, P1 to P5) to hypereutrophic in P6 and P7 (Table 9). Thus,

- In stations close to sources P0 and P1, they are of the $\mathrm{N}$-autotrophic type tolerant of high nitrogen, $\beta$-mesosaprobous and eutrophic concentrations. The floristic procession of station $\mathrm{P} 1$ is dominated by forms with low ecological weight euryece: Achnanthes minutissima, Cocconeis placentula, Navicula cryptotenella, Cymbella affinis. While at station P0 the most represented taxa are: Achnanthes minutissima, Nitzschia dissipata, Cymbella affinis and Achnanthes lanceolata.

- At the P2 and P3 stations, the diatomic community is of the obligatory N-heterotrophic type needing continuously elevated concentration of organically bound nitrogen, eutrophic $\beta$-mesosaprobous and requiring moderate oxygenation. The diatomic assembly is dominated mainly by the taxa Nitzschia palea, Navicula capitata, Nitzschia frustulum with also (in station P3) Navicula recens and Nitzschia amphibia.

- In the intermediate stations (P4 and P5) the community of epilithic diatoms is dominated by Amphora pediculus, Achnanthes minutissima, Gomphonema parvulum, Cymbella affinis to which the taxon Cymbella amphicephala is added in station P5. These assemblies would be the result of a relative improvement in the ecological conditions in these two stations following the self-cleaning phenomenon in the two stations in addition to the phenomenon of dilution by the waters of the tributary of the Bouskoura stream Ain Joumaa. Thus, we go from a mandatory N-heterotrophic diatomic community needing continuously elevated concentration of organically bound nitrogen, eutrophic, $\beta$-mesosaprobous and requiring moderate oxygenation. in station P3 to N-autotrophic communities tolerant of high levels of organic nitrogen compounds, dissolved oxygen continuously high, and $\beta$-mesosaprobous.

- In stations P6 and P7 (impacted by discharges from Nassim urban agglomerations and from the Lissassfa-SidiMaarouf industrial zone), the Nitzschiaceae family represent more than $80 \%$ of the individuals surveyed. The benthic diatom communities of these stations are composed of the following taxa: Nitzschia palea, Nitzschia capitellata, Nitzschia frustulum, in addition to Navicula capitata in station P6 and Nitzschia microcephala in station P7. The diatomic communities is therefore of obligatory N-heterotrophic type needing continuously elevated concentration of organically bound nitrogen, hypereutrophic, polysaprobous and very little oxygen requirement.

Jaccard similarity coefficient (1901): Overall, the values of this coefficient taken as the index of similarity between pairs of readings are low (Table 10); they do not exceed $30 \%$. The high values of this index can be observed either between the P0, P1, P4 and P5 stations which are not very polluted (or showing a certain recovery of their physicochemical quality) or between polluted stations with highly polluted (P2, P3, P6 and P7). This result confirms the relatively high degree of differentiation of the diatomic communities between these two groups. In the sense of De Bello et al. (2007), we can say in this case that, for each pair of habitats compared, the species are almost completely different indicating different environmental conditions that determine a turnover of important species.

Diatomic community and water quality: The evolution of the \% PTV index along Bouskoura stream seems to respond to changes in organic pollution in this environment (Fig. 2). Thus, in the P0, P1, P4 and P5 stations, the values of this index are less than $20 \%$, which suggests that organic pollu-

Table 10: Similarity of the diatom assemblage between the different stations of the Bouskoura stream according to the Jaccard index (1902) expressed as a percentage.

\begin{tabular}{|c|c|c|c|c|c|c|c|c|}
\hline & $\mathrm{P} 0$ & $\mathrm{P} 1$ & $\mathrm{P} 2$ & P3 & P4 & P5 & P6 & P7 \\
\hline \multicolumn{9}{|l|}{ P0 } \\
\hline $\mathrm{P} 1$ & 29.17 & & & & & & & \\
\hline $\mathrm{P} 2$ & 4.55 & 7.41 & & & & & & \\
\hline P3 & 7.70 & 10.00 & 13.04 & & & & & \\
\hline $\mathrm{P} 4$ & 17.39 & 23.08 & 8.70 & 11.54 & & & & \\
\hline P5 & 24.00 & 24.14 & 11.54 & 6.45 & 23.08 & & & \\
\hline P6 & 4.35 & 11.54 & 29.41 & 30.00 & 13.64 & 11.54 & & \\
\hline P7 & 7.60 & 7.41 & 29.41 & 18.18 & 13.64 & 11.54 & 22.22 & \\
\hline
\end{tabular}


tion would be absent (especially in the first two stations) at very low especially in P4 and P5 stations where the effect of a self-purification phenomenon is noted. On the other hand, the \% PTV values in P2 and P3 stations indicate (according to the Kelly 1998 classification) that the organic pollution generated respectively by the untreated wastewater from the Oulad Saleh (P2) industrial zone and the Oulad Malek and Oulad Ammor (P3) is likely to contribute significantly to eutrophication. In the stations located downstream of Bouskoura stream (S6 and S7) the contamination of water by organic pollution is very high and the \% PTV is of the order of $80 \%$ at station S6 because of the inputs of wastewater from urban agglomerations of the Nassim city. This index is close to $100 \%$ in the Lissassfa-Sidi Maârouf industrial zone (station S7). The pollutant-tolerant diatomic community is composed mainly of polysaprobic species belonging mainly to the family of Nitzschiaceae.

The results of this study are consistent with those of Jarvie et al. (2002) who observed increases in the \% PTV index downstream of wastewater treatment facilities indicating that organic pollutants contributed significantly to the observed eutrophic conditions. Fore \& Grafe (2002) found that the number of eutrophic species (\% PTV) correlated significantly with human disturbance.

In addition, changes in the \%PTV index appear to be in good agreement with the results of organic load analyses (in particular $\mathrm{BOD}_{5}, \mathrm{COD}$ and dissolved oxygen) in Bouskoura stream. The correlation test between the organic pollution index (OPI) and the four biological indices [species richness $\mathrm{S}$, specific diversity H', regularity or equitability $\mathrm{E}$ and the percentage of tolerant valves (\%PTV)] of Table 11 shows that the best correlation is obtained between \% PTV and the IPO index. This correlation is highly significant $(\mathrm{p}<0.01)$. This result means that changes in diatom communities would be the result of changes in nutrient and organic inputs.

\section{Typology of diatomic communities in Bouskoura stream:}

Principal Component Analysis (PCA), applied to a matrix of 28 diatom taxa (with a cumulative relative abundance greater than or equal to $5 \%$ ) and 8 stations, allowed to visualize the main features of the spatial distribution of these taxa (Fig. 3). The first two factor axes of the PCA represent nearly half of the total information expressed by the data matrix.

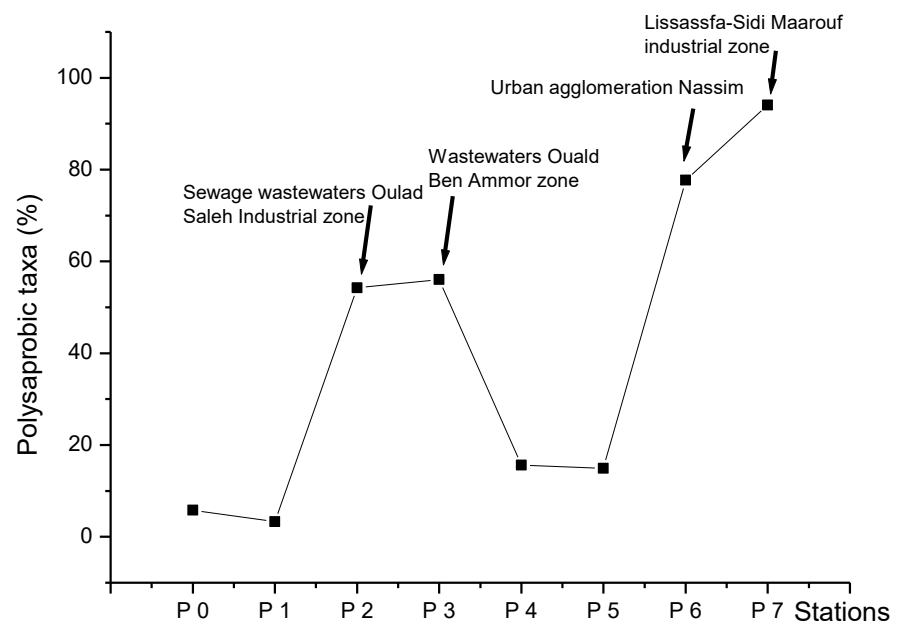

Fig. 2: Evolution of the percentage of tolerant valves (\%PTV) at the Bouskoura stream stations.

Table 11: Spearman rank correlation coefficient calculated between diatom specific richness (S), specific diversity (H'), Pielou index (E) and the per cent pollution-tolerant valves (\%PTV) along the Bouskoura stream during the study period.

\begin{tabular}{|c|c|c|c|c|c|}
\hline & Richness (S) & Diversity (H') & Eveness (E) & $\%$ PTV & OPI \\
\hline Richness (S) & 1.00 & - & - & - & - \\
\hline Diversity (H') & $0.85^{* *}$ & 1.00 & - & - & - \\
\hline Eveness (E) & 0.62 & $0.91 * *$ & 1.00 & - & - \\
\hline$\%$ PTV & $-0.72 *$ & $-0.72 *$ & -0.60 & 1.00 & \\
\hline OPI & 0.59 & 0.55 & 0.45 & $-0.94 * *$ & 1.00 \\
\hline
\end{tabular}

*significatif Correlations at $\mathrm{p}<0.05$

***significatif Correlations at $\mathrm{p}<0.01$ 
Axis 1 alone accounts for $30.84 \%$ of the total information. The stations are distributed along this axis according to an increasing pollution gradient (from left to right), with, at one end, the unpolluted stations ( $\mathrm{P} 0$ and $\mathrm{P} 1$ stations) or reflecting the sewerage effect (P4 and P5) and at the other end the stations subjected to the direct influence of the discharges of human activities (P2, P3, P6 and P7).

The 28 species of epilithic algae are distributed in the F1x F2 plane according to a sensitivity (or resistance) gradient to pollution, represented by the axis 1 . Thus, three groups of taxa become individualized in this plane (Fig. 3).

Group 1 contains the diatomic species and varieties of the sources (P0 and P1 stations) characterized by well-oxygenated waters and with low organic and trophic pollution. The diatomic communities of these stations are dominated by pollution-sensitive taxa. These are Achnanthese minutissima (AMIN), Cocconeis placentula (CPLA), Nitzschia constricta (NCOT), Achnanthes lanceolata (ALAN), Cymbella cuspidata (CCUS), Navicula cryptotenella (NCRY), Cymbella sinuata (CSIN), Amphora ventricosa (AVNT), Ntizschia dissipata (NDIS). Among these taxa, AMIN and CPLA show the strongest correlations with factorial axis $1(0.87$ and 0.59 respectively). Walsh \& Wepener (2009) reported that along the Crocodile and Magalies Rivers, reference or natural sites showed strong associations of A. minutissima with $C$. placentula.

The results of the work on certain taxa of this group such as Achnanthes lanceolata, Navicula cryptotenella and Ntizschia dissipata by Juttner et al. (1996), C. placentula by Juttner et al. (1996), Sabanci (2014), Becer et al. (2017) corroborate with those obtained in this work.

Group 2 is located on the "polluted" side of the gradient and is composed of species characteristic of environments strongly impacted by organic matter and showing an oxygen deficit. It is in this group that most of the taxa belonging to the family Nitzschiaceae are found. Nitzschia capitellata (NCPL), Nitzschia frustulum (NIFR), Nitzschia amphibia (NAMP) and Navicula recens (NRCS) have the largest contributions to the factorial axis 1 and the strongest correlations to it (i.e. $0.97,0.86,0.81$ and -0.72 respectively). In Mediterranean streams, NPAL and NIFR are described as type-specific for river sections affected by intensive agricultural and industrial activities (Tornés et al. 2007) and as highly tolerant and resistant to organic pollution (Vidal \& Gentili 2000, Fawzi et al. 2001, Fawzi et al. 2002, Tornés et al. 2007).

In addition to these species, group 2 includes Nitzschia microcephala (NMIC), Reimeria sinuata (RSIN), Navicula hungarica (NHUN), Navicula capitata (NCAP), Diatoma problematica (DPRO), Fragilaria pulchella (FPUL) and
Nitzschia palea (NPAL). The last 4 species have correlations with the F1 axis equal to $-0.67 ;-0.65 ;-0.60$ and -0.54 respectively. These pollution-tolerant species characterize the stations where there is strong organic pollution of domestic and/or industrial origin, materialized by low concentrations in oxygen but very high in $\mathrm{COD}, \mathrm{BOD}_{5}$, $\mathrm{NO}_{2}^{-}, \mathrm{NH}_{4}^{+}, \mathrm{PO}_{4}{ }^{3-}$ and total phosphorus.

The Nitzschia capitellata (NCPL), Nitzschia frustulum (NIFR), Nitzschia amphibia (NAMP) and Navicula recens (NRCS) taxa have the largest contributions to the factorial axis 1 as well as the strongest correlations to it (i.e. 0.97, $0.86,0.81$ and -0.72 respectively).

The same results were obtained for Navicula recens by Ponsati et al. (2016), Nitzschia capitellata by Szczepocka et al. (2018); Nitzschia frustulum by Taylor et al. (2007a), Gomà et al. (2004), Ponsati et al. (2016) and Demir (2019); Nitzschia palea by Juttner et al. (1996), Gomà et al. (2004), Rimet et al. (2004), Bere et al. (2014), Nehar et al. (2015), Ponsati et al. (2016), Szczepocka et al. (2018), Letáková (2018); and Reimeria sinuata by Jakovljevi et al. (2016) and Ponsati et al. (2016).

The assembly of group 3 taxa reflects the environmental remediation effect observed in the $\mathrm{P} 4$ and $\mathrm{P} 5$ stations following the self-purification and/or water dilution of the Bouskoura mainstream by the waters of its tributary Ain Joumaa.

The group 3 is composed of the following taxa: Cymbella affinis (CAFF), Amphora pediculus (APED), Fragilaria ulna (FULN). These 3 taxa show the strongest correlations with the $\mathrm{F} 1$ axis $(0.74,0.63$ and 0.55 respectively). In this group, we also find the following taxa: Cymbella amphicephala (CAPH), Amphora veneta (AVEN), Gomphonema parvulum (GPAR) as well as Navicula cincta (NCIN) and Diploneis ovalis (DOVA).

The work of Kivrak \& Uygun (2012) showed that in the Turkish Akarçay stream (highly polluted), Amphora pediculus, Amphora veneta and Cocconeis placentula are dominant upstream of the polluted area. Becer et al. (2017) reported that Cymbella affinis is frequently developed as benthic, especially in rivers and is dominant in clean waters.

Name of diatom taxa: AMIN: Achnanthese minutissima, CPLA: Cocconeis placentula, NCOT: Nitzschia constricta, ALAN: Achnanthes lanceolata, CCUS: Cymbella cuspidate, NCRY: Navicula cryptotenella, CSIN: Cymbella sinuata, AVNT: Amphora ventricosa, NDIS: Ntizschia dissipata, NCPL: Nitzschia Capitellata, NIFR: Nitzschia frustulum, NAMP: Nitzschia amphibia, NRCS: Navicula recens, NMIC: Nitzschia microcephala, RSIN: Reimeria sinuata, NHUN: Navicula hungarica, NCAP: Navicula capitata, DPRO: Diatoma problematica, FPUL: Fragilaria 


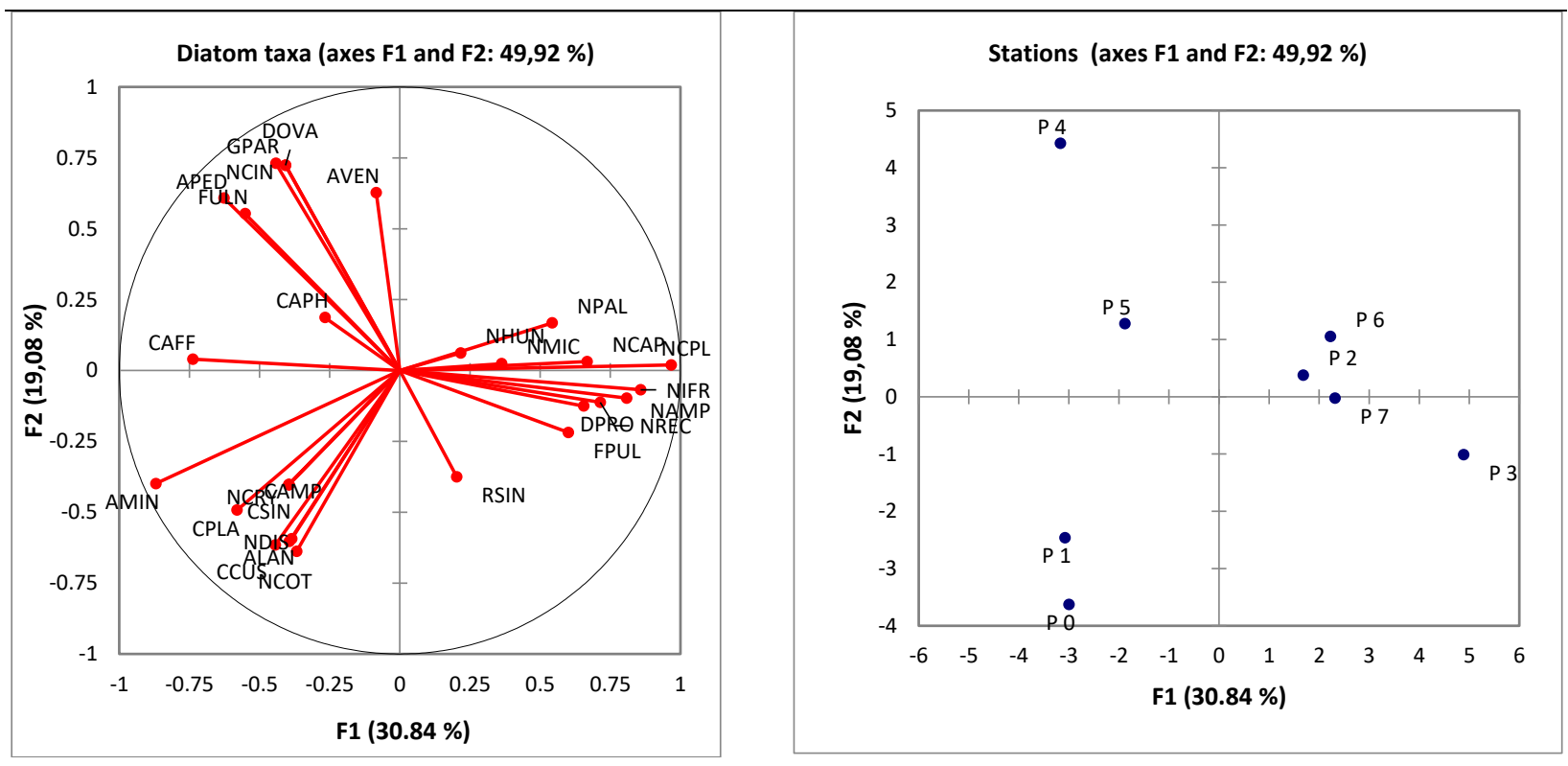

Fig. 3: projections on the factorial plane $\mathrm{F} 1 \mathrm{xF} 2$ of the $\mathrm{ACP}$ of the species and varieties of diatoms ( $5 \%$ of cumulative relative abundance) (on the left) and of the 8 stations prospected in the Bouskoura stream (on the right).

pulchella, NPAL: Nitzschia palea, CAFF: Cymbella affinis, APED: Amphora pediculus, FULN: Fragilaria ulna, CAPH: Cymbella amphicephala, AVEN: Amphora veneta, GPAR: Gomphonema parvulum, NCIN: Navicula cincta, DOVA: Diploneis ovalis

Station names: P0: Ain Joumaa Source, P1: Bouskoura Sources, P2: Noukhayla, P3: Laghchiwa, P4: Oulad malek, P5: Sidi Ayyad P6: Nassim Agglomerations, P7: Lissasfa Sidi maarouf Industrial Zone.

\section{Correlation between diatomic flora and physicochemical} parameters of water: Table 12 presents the Spearman rank correlation coefficient (for $\mathrm{p}<0.05$ and $\mathrm{p}<0.01$ ) calculated between some physicochemical variables of water and the average relative abundance of taxa (with a cumulative relative abundance greater than or equal to $5 \%$ )

The Achnanthese minutissima (AMIN), Cocconeis placentula (CPLA) and Cymbella affinis (CAFF) taxa appear to develop better when pollution parameters are low. Indeed, these three species are negatively correlated with all the pollution parameters, in particular the KTN, with which they have significant correlations ( $\mathrm{p}<0.05)$.

In the Bouskoura stream, the relative abundance of the diatom A. minutissima shows highly significant $(\mathrm{p}<0.01)$ and positive correlations with dissolved oxygen but negative correlations with phosphorus elements. Moreover, the correlations of this species with the three pollution indicators (SM, COD and nitrites) are significant $(\mathrm{p}<0.05)$. In accordance with the works of Prygiel \& Coste (1993), Leclercq et al. (1996) and Abd El-Karim (2014), this species is therefore low organic matter content indicator.

C. placentula can tolerate mesotrophic to eutrophic conditions (Van Dam et al. 1994, Taylor et al. 2007b). The findings of this study are in agreement with the findings of Kivrak \& Uygun (2012), who found that in Akarçay stream (Turkey), C. placentula is prevalent at upstream with clean, freshwaters and well-oxygenated sites.

In contrast, the relative abundance of $N$. palea (NPAL) shows highly significant $(\mathrm{p}<0.01)$ and negative correlation with oxygen, but positive with total phosphorus, orthophosphate, COD and nitrites. The same species shows a positive correlation and significant $(\mathrm{p}<0.05)$ for $\mathrm{BOD}_{5}$ and ammonium. Kivrak \& Uygun (2012) have shown that in the Akarçay stream, the abundance of this taxon is strongly and positively correlated with $\mathrm{BOD}_{5}, \mathrm{COD}$ and nutrients. In the Seydisuy stream basin (Turkey), N. palea is highly correlated ( $\mathrm{p}<$ 0.01) with nitrites (Atici et al. 2018).

Nitzschia capitellata (NCPL) shows a significant ( $p$ $<0.05$ ) and negative correlation with dissolved but positive oxygen with three KTN pollution parameters, nitrites and total phosphorus. The correlation with this last parameter is highly significant $(\mathrm{p}<0.01)$. According to Krammer \& Lange-Bertalot (1986), Van Dam et al. (1994) and Rimet et al. (2004) this taxon is $\alpha$-meso-polysaprobic to polysaprobic and eutrophic.

Nitzschia microcephala (NMIC) also has a negative but insignificant correlation with dissolved oxygen. The 
correlations of the abundances of this taxon with the pollution parameters are positive, in particular the COD and the $\mathrm{BOD}_{5}$ with which these correlations are significant $(\mathrm{p}<0.05)$ and the ammonium $\mathrm{NH}_{4}^{+}$with which this correlation is highly significant $(\mathrm{p}<0.01)$. According to Van Dam et al. (1994), N. microcephala (NMIC) characterizes eutrophic and $\alpha$-mesosaprobic media. NMIC also shows a negative correlation with dissolved oxygen. The correlations of the abundances of this taxon with the pollution parameters are positive, in particular, the $\mathrm{DOC}$ and $\mathrm{BOD}_{5}$ with which these correlations are significant $(\mathrm{p}<0.05)$ and the ammonium $\mathrm{NH}_{4}^{+}$with which this correlation is highly significant $(\mathrm{p}<0.01)$.

\section{CONCLUSIONS}

This work is a first ecological study conducted on the diatomic communities of Bouskoura stream which are subjected to natural and anthropogenic disturbances. At the end of this study, the following conclusions can be drawn.

- The evolution of the average environmental descriptors has shown that the waters of this ecosystem are characterized by significant mineralization and an increasing gradient (upstream-downstream) of organic pollution linked to discharges of untreated liquid discharges from domestic, industrial and agricultural sources. In view of the physicochemical analyses, the situation would

Table 12: Spearman rank correlation coefficient calculated between diatom taxa and physicochemical parameters of Bouskoura stream waters.

\begin{tabular}{|c|c|c|c|c|c|c|c|c|c|c|c|c|c|}
\hline Taxa & $\mathrm{pH}$ & $\mathrm{T}$ & $\mathrm{CE}$ & $\mathrm{O}_{2}$ & $\mathrm{SM}$ & $\mathrm{PO}_{4}{ }^{3-}$ & DCO & $\mathrm{BOD}_{5}$ & NTK & $\mathrm{NH}_{4}^{+}$ & $\mathrm{PT}$ & $\mathrm{NO}_{2}^{-}$ & Chl. a \\
\hline AMIN & -0.44 & 0.06 & -0.66 & $0.86^{* *}$ & $-0.73^{*}$ & $-0.89 * *$ & $-0.73^{*}$ & -0.58 & $-0.81 *$ & -0.64 & $-0.94 * *$ & $-0.72 *$ & -0.35 \\
\hline ALAN & -0.36 & 0.52 & -0.62 & 0.49 & -0.66 & -0.55 & -0.38 & -0.28 & -0.54 & -0.26 & -0.52 & -0.28 & -0.44 \\
\hline CPLA & -0.53 & -0.43 & -0.64 & 0.69 & -0.65 & -0.62 & -0.51 & -0.44 & $-0.80^{*}$ & -0.41 & -0.69 & -0.54 & -0.53 \\
\hline DPRO & -0.32 & 0.18 & 0.17 & 0.09 & 0.18 & 0.02 & -0.02 & -0.00 & 0.29 & 0.11 & 0.11 & -0.09 & 0.04 \\
\hline FULN & 0.21 & -0.03 & 0.29 & 0.23 & 0.15 & -0.37 & -0.29 & -0.13 & 0.10 & -0.33 & -0.39 & -0.36 & 0.49 \\
\hline FPUL & -0.49 & 0.30 & -0.01 & 0.22 & -0.01 & -0.16 & -0.20 & -0.13 & 0.26 & -0.03 & -0.02 & -0.17 & 0.10 \\
\hline CAFF & 0.08 & -0.25 & -0.22 & 0.55 & -0.13 & -0.38 & -0.43 & -0.53 & $-0.71 *$ & -0.54 & -0.61 & -0.70 & -0.27 \\
\hline CSIN & -0.52 & -0.40 & -0.50 & 0.52 & -0.56 & -0.53 & -0.39 & -0.26 & -0.52 & -0.26 & -0.52 & -0.35 & -0.35 \\
\hline CCUS & -0.38 & 0.45 & -0.66 & 0.55 & -0.69 & -0.58 & -0.42 & -0.33 & -0.62 & -0.31 & -0.57 & -0.35 & -0.49 \\
\hline CAPH & 0.26 & -0.52 & 0.06 & 0.14 & 0.24 & 0.14 & -0.06 & -0.30 & -0.42 & -0.24 & -0.11 & -0.38 & -0.21 \\
\hline APED & 0.42 & 0.09 & 0.32 & 0.23 & 0.27 & -0.27 & -0.28 & -0.24 & -0.04 & -0.41 & -0.39 & -0.47 & 0.41 \\
\hline AVEN & 0.61 & 0.06 & 0.33 & -0.33 & 0.47 & 0.42 & 0.34 & 0.23 & 0.21 & 0.14 & 0.29 & -0.13 & 0.21 \\
\hline GPAR & 0.65 & -0.25 & 0.57 & -0.01 & 0.59 & 0.10 & 0.02 & -0.08 & 0.00 & -0.18 & -0.11 & -0.32 & 0.29 \\
\hline NCRY & -0.52 & -0.40 & -0.50 & 0.52 & -0.56 & -0.53 & -0.39 & -0.26 & -0.52 & -0.26 & -0.52 & -0.35 & -0.35 \\
\hline NREC & -0.37 & 0.36 & 0.07 & 0.04 & 0.10 & 0.03 & -0.02 & 0.05 & 0.40 & 0.13 & 0.17 & -0.09 & 0.12 \\
\hline NCIN & 0.42 & 0.13 & 0.49 & 0.03 & 0.37 & -0.17 & -0.14 & -0.03 & 0.30 & -0.23 & -0.19 & -0.23 & 0.64 \\
\hline NHUN & -0.07 & -0.50 & -0.07 & -0.37 & -0.03 & 0.26 & -0.11 & -0.28 & 0.24 & -0.26 & 0.34 & 0.60 & 0.53 \\
\hline NCAP & -0.07 & 0.47 & 0.09 & -0.24 & 0.18 & 0.31 & 0.30 & 0.33 & 0.46 & 0.37 & 0.41 & 0.04 & 0.05 \\
\hline RSIN & -0.46 & 0.26 & -0.27 & 0.49 & -0.20 & -0.32 & -0.39 & -0.40 & -0.25 & -0.27 & -0.31 & -0.47 & -0.23 \\
\hline DOVA & 0.42 & 0.13 & 0.49 & 0.03 & 0.37 & -0.17 & -0.14 & -0.03 & 0.30 & -0.23 & -0.19 & -0.23 & 0.64 \\
\hline CAMP & -0.52 & -0.40 & -0.50 & 0.52 & -0.56 & -0.53 & -0.39 & -0.26 & -0.52 & -0.26 & -0.52 & -0.35 & -0.35 \\
\hline NCOT & -0.25 & 0.41 & -0.42 & 0.34 & -0.57 & -0.44 & -0.08 & 0.10 & -0.49 & 0.11 & -0.41 & -0.06 & -0.66 \\
\hline NIFR & -0.03 & 0.47 & 0.36 & -0.34 & 0.34 & 0.38 & 0.51 & 0.59 & 0.59 & 0.67 & 0.51 & 0.29 & -0.07 \\
\hline NDIS & -0.37 & 0.51 & -0.63 & 0.50 & -0.67 & -0.56 & -0.39 & -0.29 & -0.55 & -0.27 & -0.53 & -0.29 & -0.45 \\
\hline NPAL & 0.50 & 0.00 & 0.39 & $-0.91 * *$ & 0.42 & $0.85^{* *}$ & $0.84 * *$ & $0.73^{*}$ & 0.56 & $0.75^{*}$ & $0.89 * *$ & $0.92 * *$ & 0.06 \\
\hline NCPL & 0.11 & 0.23 & 0.39 & $-0.72 *$ & 0.40 & 0.68 & 0.66 & 0.63 & $0.76^{*}$ & 0.71 & $0.84 * *$ & $0.75^{*}$ & 0.15 \\
\hline NAMP & -0.23 & -0.06 & 0.23 & -0.35 & 0.20 & 0.31 & 0.14 & 0.10 & 0.56 & 0.20 & 0.48 & 0.57 & 0.33 \\
\hline NMIC & 0.46 & 0.13 & 0.51 & -0.62 & 0.40 & 0.56 & $0.80^{*}$ & $0.82 *$ & 0.37 & $0.85^{* *}$ & 0.58 & 0.69 & -0.24 \\
\hline
\end{tabular}

$*$ : significatif Correlations at $\mathrm{p}<0.05$

$* *$ : significatif Correlations at $\mathrm{p}<0.01$

Name of diatom taxa abbreviated as per Table 3 
be alarming in the stations located downstream of the watercourse (in particular stations P6 and P7). However, there is a tendency to improve the quality of the water downstream of the P4 site and upstream of the P5 site following the dilution of the pollutant load by the waters of the Bouskoura tributary (Ain Joumaa) as well as the water treatment process self-purification;

- The diatomic flora is predominantly alkaliphilic and characterizes $\beta$-mesoseprobes to polysaprobes, eutrophic to hypereutrophic media. It has a total of 54 species and varieties corresponding to 27 genera and belonging to 5 main families (the Monoraphids, the Naviculaceae, the Nitzschiaceae, the Aripidae and Surirellaceae) and have no particularity with respect to that observed in the Mediterranean area.

- The change in the percentage of pollutant-tolerant taxa was the best indicator of the magnitude of the impact of environmental stress and human activities on the natural waters of the Bouskoura watercourse.

- The exploitation of the data of this study confirms that the diatoms are excellent indicators of the overall water quality of Bouskoura stream especially with regard to saprobia and trophic status and this study represents a contribution to a future database on the study of diatoms in Moroccan rivers.

\section{REFERENCES}

Becer, Z.A., Yuce, A.M. and Kalyoncu, H. 2017. Epilithic diatom composition and some physico-chemical parameters of the streams in the Çoruh Basin (Turkey). International Journal of Contemporary Research and Review. 8(11): 20252-20257.

Bellinger, B. J., Cocquyt, C. and O'Reilly C.M. 2006. Benthic diatoms as indicators of eutrophication in tropical streams. Hydrobiologia, 573: $75-87$

Benhassane, L., Loudiki, M., Fadlaoui, S., Belhouari A. and Oubraim S. 2019. Monitoring impacts of human activities on Bouskoura stream (periurban of Casablanca, Morocco): 1. Physico-chemistry. Indian Journal of Applied Research, 9(1): 41-49.

Bere, T., Mangadze, T. and Mwedzi, T. 2014. The application and testing of diatom-based indices of stream water quality in Chinhoyi Town, Zimbabwe. Water SA, 40(3): 503-512.

Bey, M.Y. and Ector, L. 2013. Atlas des diatomées des cours d'eau de la région Rhône-Alpes. Direction régionale de l'Environnement, de l'Amenagement et du Logement Rhone-Alpes (ed.), Lyon, pp. 1182.

Boudaoud, Y. and Haddine, A. 2013. Collecte des eaux pluviales du bassin de Bouskoura. Mémoire de projet de fin d'études pour l'obtention du diplôme d'Ingénieur d'Etat en Génie Civil de l'EHTP, pp. 127.

Burfeid Castellanos, A. M. 2018. Ecological Factors and Diatom Diversity at Rivers of the Iberian Mediterranean River Basins: Macro-scale, Mesoscale and Micro-scale. PhD Thesis of Barcelona University, pp. 233.

Cazaubon, A. and Badri, A. 1994. Influence des variations hydrodynamiques de l'oued Tensift (Maroc) sur les peuplements de Diatomées. Ecologia Mediterranea, XX (112): 97-108.

Çelekli, A. and Bilgi, F. 2019. Bioassessing ecological status of surface waters in the Araban-Yavuzeli catchment (Turkey): application of diatom indices. Turkish Journal of Botany, 43: 597-607.
CEMAGREF 1982. Étude des méthodes biologiques d'appréciation quantitative de la qualité des eaux. Rapport Division qualité des eaux Cemagref Lyon. Agence de l'eau Rhône-Méditerranée-Corse, Lyon: $218 \mathrm{p}$.

Daget, J. 1976. Les modèles mathématiques en écologie. In Masson (ed.), Paris, pp. 172.

De Bello, F., Lepš, J., Lavorel, S. and Moretti, M. 2007. Importance of species abundance for assessment of trait composition: An example based on pollinator communities. Community Ecology, 8(2): 163-170.

Demir, C.T. 2019. The use of phytobenthos for the ecological status assessment in upper Sakarya Basin, Turkey (Turkey). Applied Ecology and Environmental Research, 17(4): 10155-10172.

Ector, L. and Rimet, F. 2005. Using bioindicators to assess rivers in Europe: An overview. In Lek, S., Scardi, M., Verdonschot, P.F.M., Descy, J.P. and Park, Y.S. (ed.) Modelling Community Structure in Freshwater Ecosystems, pp. 7-19, Springer Verlag, Berlin Heidelberg.

Fawzi, B., Chlaida, M., Oubraim, S., Loudiki, M., Sabour, B. and Bouzidi, A. 2001. Application de certains indices diatomiques à un cours d'eau marocain: Oued Hassar. Revue des Sciences de l'Eau/Journal of Water Science, 14(1): 73-89.

Fawzi, B., Loudiki, M., Oubraim, S., Sabour, B. and Chlaida, M. 2002. Impact of wastewater effluent on the diatom assemblages structure of a brackish small stream: Oued Hassar (Morocco). Limnologica, 32: 54-65.

Fekhaoui, M., Hamada, S. and Dakki, M. 1988. Fonctionnemnt de l'Oued Sebou à l'aval de la ville de Fès: étude du peuplement d'algues benthiques. Bulletin de l' Institut Scientifique Rabat, 12: 59-68.

Fièvet, E., Prompt, P. and Martinez, P.J. 2003. Utilisation des indices biologiques pour évaluer l'état écologique des cours d'eau au sens de la Directive Cadre sur l'Eau. Rapport final de l'étude Interagences. Agence de l'eau (ed.), pp.128 + 2 annexes.

Fore, L. S. and Grafe, C. 2002. Using diatoms to assess the biological condition of large rivers in Idaho (USA). Freshwater Biology, 47: 2015-2037.

Gattefosse, J. 1935. Contribution à l'étude de la flore cryptogamique du Maroc (Bryophytes, Algae, Lichens et Fungi). Bull. Soc. Hist. Nat. Afr. N., 26(3): 72-85.

Gauthier, L. 1930. Note d'algologie marocaine. Bulletin de la Société d'histoire naturelle d'Afrique du Nord, 21: 189-192.

Gayral, P. 1954. Recherches phytolimnologique au Maroc. Travaux de 1' lnstitut Scientifique Chérifiènne, série Botanique, 4, pp. $305+14$ plates.

Golterman H.L. 1971. Methods for Chemical Analysis of Freshwaters. International Biological Programme $\mathrm{N}^{\circ}$ 8, Handbook, Blackwell Scientific (ed.), London, Oxford, pp. 166.

Gomà, J., Rimet, F., Cambra, J., Hoffmann, L. and Ector L. 2005. Diatom communities and water quality assessment in Mountain Rivers of the upper Segre basin (La Cerdanya, Oriental Pyrenees). Hydrobiologia, 551: 209-225.

Goury, M. and Chelhaoui, Y. 2013. Evaluation des scénarios des changements climatiques locaux via le modèle SDSM pour une zone de montagne et une zone de plaine. Mémoire de projet de fin d'études pour l'obtention du diplôme d'Ingénieur d'Etat de l'EHTP, pp. 162.

Hariot, R.L. 1909. Sur une collection d'Algues recueillies au Maroc par Buchet. Bulletin Museum de Paris,15: 128-130.

Jaccard, P. 1901. Etude Comparative de la distribuition florale dans une portion des Alpes et des Jura. Bulletin de la Société Vaudoise des Sciences Naturelles, 7: 547-579.

Jaghror, H., Serieyssol, K., Beauger, A., Loukili, K. and Fadli, M. 2017. Diatom diversity and ecology of the Sebou watershed (Morocco). Biolife, 5(4): 564-577.

Jakovljevi , O.S., Popovi , S.S., Vidakovi, D.P, Stojanovi, K.Z. and Krizmani 2016. The application of benthic diatoms in water quality assessment (Mlava River, Serbia). Acta Botanica Croatica, 75(2): 199-205. 
Jarvie, H. P., Lycett, E., Neal, C. and Love, A. 2002. Patterns in nutrient concentrations and biological quality indices across the upper Thames river basin, UK. The Science of the Total Environment, 282-283: 263-294.

Juttner, I., Rothfritz, H. and Ormerod, S.J. 1996. Diatoms as indicators of river quality in the Nepalese Middle Hills with consideration of the effects of habitat-specific sampling. Freshwater Biology, 36: 475-486.

Kelly, M.G. 1998. Use of the trophic diatom index to monitor eutrophication in rivers. Water Research, 32(1): 236-242.

Kelly, M.G. and Whitton, B.A. 1995. The Trophic Diatom Index: A new index for monitoring eutrophication in rivers. Journal of Applied Phycology, 7: 433-444.

Kivrak, E. and Uygun, A. 2012. The structure and diversity of the epipelic diatom community in a heavily polluted stream (the Akarçay, Turkey) and their relationship with environmental variables. Journal of Freshwater Ecology, 27(3): 443-457.

Kollár, J., Fránková, M., Hašler, P., Letáková, M. and Poulí ková, A. 2015. Epiphytic diatoms in lotic and lentic waters - Diversity and representation of species complexes. Fottea, 15(2): 259-271.

Krammer, K. and Lange-bertalot, H. 1986. Bacillariophyceae. Tome 1: Naviculaceae. Semper Bonis Artibus, pp. 876.

Krammer, K. and Lange-bertalot, H. 1988. Bacillariophyceae. Tome 2: Bacillariaceae, Epithemiaceae et Surirellaceae. Semper Bonis Artibus, pp. 596.

Krammer, K. and Lange-bertalot, H. 1991a. Bacillariophyceae. Tome 3: Centrales, Fragilariaceae, Eunotiaceae. Semper Bonis Artibus, pp. 576.

Krammer, K. and Lange-bertalot, H. 2000. Bacillariophyceae (Tome 5). Semper Bonis Artibus. English and French translation of the Keys, pp. 311.

Krammer, K. and Lange-bertalot, H.1991b. Bacillariophyceae. Tome 4: Achnanthaceae. Semper Bonis Artibus, pp. 437.

Lange-Bertalot, H. 1979. Pollution tolerance of diatoms as a criterion for water quality estimation. Nova Hedw., 64: 285-304.

Leclercq, L. and Maquet, B. 1987. Deux nouveaux indices chimiques et diatomiques de la qualité d'eau courante. Application au Samson et à ses affluents (Bassin de la Meuse Belge). Comparaison avec d'autres indices chimiques, biologiques et diatomiques. Inst. Roy. Sci. Nat. Belgique. Document de travail 38: pp. 98.

Leclercq, L. and Vandevenne, L. 1987. Impact d'un rejet d'eau chargée en sel et d'une pollution organique sur les peuplements de diatomées de la Gander (Grand-Duché du Luxembourg). Cahiers de Biologie Marine, 28: 311-317.

Leclercq, L., Rosillon, F. and Van Der Borght, P. 1996. Qualité chimique et biologique du bassin de la Semois. Bulletin français de la pêche et de la pisciculture. 341/342: 81-108.

Letáková, M., Fránková, M. and Poulí ková, A. 2018. Ecology and applications of freshwater epiphytic diatoms - review. Cryptogamie, Algologie, 39(1): 3-22.

Maiffi-Rassat, M. 1988. La flore algale de l'Oued Tensift : Impact des eaux usées de la ville de Marrakech (Maroc). Les diatomées, indicateurs biologiques de la qualité des eaux. Thèse 3èrne Cycle, Univ. Paris, pp. 234.

Menye, E.D., Togouet, S.H.Z., Menbohan, S. F., Kemka, N., Nola, M., Boutin, C., Nguetsop, V.F,. Moussa D. and Njiné, T. 2012. Bio-écologie des diatomées épilithiques de la rivière Mfoundi (Yaoundé, Cameroun): diversité, distribution spatiale et influence des pollutions organiques. Revue des sciences de l'eau / J. Water Sci., 25(3): 203-218.

Morin, S. 2006. Bioindication des effets des pollutions métalliques sur les communautés de diatomées benthiques approches in situ et expérimentales. Thèse de Doctorat de L'Université de Bordeaux 1: $306 \mathrm{p}$.

Morin, S. and Coste, M. 2006. Atlas des Diatomées du Bassin Versant du Riou-Mort. Cemagref: Bordeaux, pp.109.

Mouni, L., Merabet, D., Arkoub, H. and Moussaceb, K. 2009. Etude et caractérisation physico-chimique des eaux de l'oued Soummam (Algérie). Sécheresse, 20 (4): 360-366.

Mounjid, J., Cohen, J., Fadlaoui, S. and Oubraim, S. 2014. Study of physicochemical and microbiological quality of Oued Bouskoura Peri-Urbain of Casablanca, Morocco. Int. Res. J. Environment Sci. International Science, 3(5): 60-66.

Nehar, B., Blanco, S. and Hadjadj-Aoul, S. 2015. Diversity and ecology of diatoms in northwest of Algeria: Case of el-hammam stream and estuary of Cheliff river. Applied Ecology and Environmental Research, 13(1): 37-52.

NF EN 13946 2003. Qualité de l'eau. Guide pour l'échantillonnage en routine et le prétraitement des diatomées benthiques des rivières. AFNOR (ed.), pp. 16.

NF T 90-354 2000. Détermination de l'Indice Biologique Diatomées (IBD). AFNOR (ed.), pp. 64.

Oubraim, S. 2002. Qualité physico-chimique et biologique des cours d'eau du réseau hydrographique de la Meseta Occidentale Marocaine: Cas de l'Oued Mellah. Thèse de doctorat d'état. Faculté des Sciences Ben M'Sik.

Patrick, R. 1971. The effects of increasing light and temperature in the structure of diatoms communities. Limnology and Oceanography, 16: 405-421.

Pielou, E.C. 1975. Ecological Diversity. John Wiley and Sons, New York, pp. 165.

Ponsati, L., Corcoll, N., Petrovic, M., Pico, Y., Ginebreda, A., Tornes, E., Guasch, H., Barcelo, D. and Sabater, S. 2016. Multiple-stressor effects on river biofilms under different hydrological conditions. Freshwater Biology, 61: 2102-2115.

Prygiel, J. and Coste, M. 2000. Guide méthodologique pour la mise en œuvre de 1'Indice Biologique Diatomées. NF T 90- 354. Agences de l'Eau-Cemagref, Bordeaux, 134 p.

Prygiel, J., Coste, M. and Bukowska, J. 1999. Review of the major diatombased techniques for the quality assessment of rivers - State of the art in Europe. In: Use of Algae for Monitoring Rivers III, Prygiel J., Whitton B. A., Bukowska J. (eds.), Agence de l'Eau Artois-Picardie, pp. 224-238.

Quevedo, L., Ibáñez, C., Caiola, N., Cid, N. and Hampel, H. 2018. Impact of a reservoir system on benthic macroinvertebrate and diatom communities of a large Mediterranean river (lower Ebro river, Catalonia, Spain). Limnetica, 37(2): 209-228.

Resende, P.C., Resende, P., Pardal, M., Almeida, S. and Azeiteiro, U. 2010. Use of biological indicators to assess water quality of the Ul River (Portugal). Environ. Monit. Assess., 10p.

Rimet, F., Cauchie H.M., Hoffmann, L. and Ector L. 2005. Response of diatom indices to simulated water quality improvements in a river. Journal of Applied Phycology, 17: 119-128.

Rimet, F., Ector, L., Cauchie, H.M. and Hoffmann, L. 2004. Regional distribution of diatom assemblages in the headwater streams of Luxembourg. Hydrobiologia, 520: 105-117.

Rimet, F., Heudre, D., Matte, J.L. and Mazuer, P. 2006. Communauté de Diatomées des Bassins Moselle, Meuse et Sarre- Correspondance avec les Hydro- Ecorégions. Diren Lorraine, 51pp.

Rimet, F., Matte, J.L. and Mazuer, P. 2006. Analyse de l'Application de Deux Indices Diatomées sur les Cours d'Eau Lorrains. I.B.D. et I.P.S.: Diren Lorraine; 1-21.

Rodier, J. and Legube, B. 2009. L'Analyse de l'eau. 9ème édition, Dunod, Paris, 1526p.

Ros, M.D., Marín-Murcia, J.P. and Aboal, M. 2009. Biodiversity of diatom assemblages in a Mediterranean semiarid stream: Implications for conservation. Marine and Freshwater Research, 60: 14-24.

Round, F.E. 1991. Diatoms in river water-monitoring studies. Journal of Applied Phycology, 3: 129-145.

Round, F.E., Crawford, R. and Mann, D. 1990. The Diatoms. Biology and Morphology of the Genera. Cambridge Univ. Press (ed.), pp. 747. 
Sabanci, F.Ç. 2014. Phytoplankton distribution and its relationship to the physico-chemical environment in a coastal lagoon. Ekoloji, 23(90): 61-72.

Shannon, C. E. and Weaver, W. 1963. The Mathematical Theory of Communication, Univ. Illinois Press, pp. 117.

Slim Kamal, Ali Atoui and Mirvat Temsah 2013. Impact des rejets de margines sur la qualité des eaux du Nahr Hasbani (Sud Liban) par référence spéciale aux indices diatomiques. Nature \& Technologie, 9: 2-12.

Solak, C.N. 2011. The application of diatom indices in the upper Porsuk Creek Kütahya-Turkey. Turkish Journal of Fisheries and Aquatic Sciences, 11: 31-36.

Solak, C.N., Barinova, S., ÁCS, E. and Dayio lu, H. 2012. Diversity and ecology of diatoms from Felent creek (Sakarya river basin), Turkey. Turk. J. Bot., 36: 191-203.

Solak, C.N., Fehér, G., Barlas, M. and Pabuçcu, K. 2007. Use of epilithic diatoms to evaluate water quality of Akçay stream (Büyük Menderes River) in Mugla/Turkey. Large Rivers, 17(3-4) (Archiv Hydrobiol. Suppl.161(3-4): 327-333).

Srivastava Prateek, Sarika Grover, Jyoti Verma and Ambrina Sardar Khan 2017. Applicability and efficacy of diatom indices in water quality evaluation of the Chambal River in Central India. Environ. Sci. Pollut. Res., 1-22p.

Stenger-Kovácsa, C., Lengyela, E., Crossettib, L.O., Üvegesa, V. and Padisáka, J. 2013. Diatom ecological guilds as indicators of temporally changing stressors and disturbances in the small Torna-stream, Hungary. Ecological Indicators, 24: 138-147.

Stoffnerr, F. 2013. Modélisation du bassin de Bouskoura avec STORM. Méthodologie du développement d'un modèle hydrologique. GIZ AGIRE. http://www.swim-sustain-water.net/fileadmin/resources/52013-06-21-SWIM-Modelisation-du-bassin-de-Bouskoura-avecSTORM-version-finale-FS-NH.pdf.

Szczepocka, E., Nowicka-Krawczyk, P. and Kruk, A. 2018. Deceptive ecological status of urban streams and rivers-evidence from diatom indices. Ecosphere, 9(7):e 02310. 10.1002/ecs2.2310, 1-17.

Taylor, J.C., Harding, W.R. and Archibald, C.G.M. 2007b. An illustrated guide to some common diatom species from South Africa. WRC Report No TT 282/07. Water Research Commission, Pretoria, South Africa, 225pp.

Taylor, J.C., Prygiel, J., Vosloo, A., De la Rey, P. A. and Van Rensburg, L. 2007a. Can diatom-based pollution indices be used for biomonitoring in South Africa? A case study of the Crocodile West and Marico water management area. Hydrobiologia, 592: 455-464.

Tazi, O., Fahde, A. and El Younoussi, S. 2001. Impact de la pollution sur l'unique réseau hydrographique de Casablanca, Maroc. Sécheresse, 12(2): 129-134.

Temizel, B., Soylu, E.N. and Mara lı lu, F. 2017. Water quality assessment of the Pazarsuyu Stream based on epilithic diatom communities. Fundam. Appl. Limnol., 190(3): 189-197.

Tokatl, C. and Dayı lu, H. 2014. Use of biological diatom index to evaluate the water quality of lotic ecosystems: A case study of Murat Stream (Kütahya, Turkey). $4^{\text {th }}$ International Conference on Environment Science and Engineering IPCBEE, IACSIT Press, Singapore, 68: 19-23.

Tornés, E., Cambra, J., Gomà, J., Leira, M., Ortiz, R. and Sabater, S. 2007. Indicator taxa of benthic diatom communities: A case study in Mediterranean streams. Ann. Limnol. Int. J. Lim., 43 (1): 1-11.

Torrisi, M., Rimet, F., Cauchie, H.M., Hoffmann, L. and Ector, L. 2006. Bioindication par les diatomées épilithiques et épiphytes dans la rivière sûre (Luxembourg). Belgian Journal of Botany, 139(1): 39-48.

Van Dam, H., Mertens, A. and Sinkeldam, J. 1994. A coded checklist and ecological indication values of freshwater diatoms from The Netherlands. Netherlands Journal of Aquatic Ecology, 28: 117-133.

Vidal, H. and Gentili, R. 2000. Evolution de la qualite d'un petit cours d'eau mediterraneen, la Bouillide, après rehabilitation d'une station d'epuration. In: Compte rendu du 18ème colloque de l'Association des diatomistes de langue francaise (Cryptogamie Algol.). Ector L., Compère P., Vidal H., Semprini M. \& Gentili R. (eds.), 245-246.

Walsh, G. and Wepener, V. 2009. The influence of land use on water quality and diatom community structures in urban and agriculturally stressed rivers. Water SA, 35(5): 579-594.

Werner, R.G. 1949. Contribution à l'étude algologique de quelques rivières marocaines. Le Botaniste, 34: 367-374.

Whitton, B.A. 1991. Aims of monitoring. In: Whitton, B.A., Rott, E. et Friedrich, G. (eds.), Use of Algae for Monitoring Rivers, pp.5-8.

Wilhm, J.L. 1975. Biological indicators of pollution. In: Whitton, B. A. (ed.) River Ecology, Studies in Ecology, Vol. 2, Blackwell Sci. Publ., Oxford, London, Edinburgh, Melbourne, pp. 725.

Yildirim, V. and Baran, N. 2019. The relationship between epilithic diatom communities and water quality variations across Tohma stream (Malatya-Turkey). Fresenius Environmental Bulletin, 28(4 A): $3043-3049$. 